\title{
Cardiogenic Shock: The Main Cause of Mortality in Acute Aluminum Phosphide Poisoning
}

Sir,

We read with interest the latest review by Farahani et al. ${ }^{[1]}$ As aluminum phosphide (ALP) is a significant issue in some toxicological centers in $\operatorname{Iran}^{[2,3]}$ and India, we think that there are some concerns about this article that is worth mentioning.

- First, the authors stated that severe hypotension in ALP poisoning was not associated with heart failure. We have significant concern about this claim. There is a large body of evidence in the literature that mentions severe cardiac dysfunction and consequently very low ejection fraction, indicating cardiogenic shock after exposure to ALP poisoning. ${ }^{[4-7]}$ Although we agree with the authors that vascular integrity insufficiency is one of contributing factors in severe hypotension in these patients, it seems that cardiogenic shock confirmed by echocardiography is more important ${ }^{[4-7]}$ In this regard, treatment of cardiogenic shock with intra-aortic balloon pump, extracorporeal membrane oxygenation, digoxin, glucose/insulin, and glucagon had interesting results in other studies. ${ }^{[4-7]}$

- The authors stated "We recommend that only vegetable oils or liquid paraffin to be used after acute ALP poisoning for a safe gastric decontamination." This claim is considered an unproved claim since just a case report supports it. Moreover, in animal studies, ALP is dissolved in almond oil before its gavage into the animal's stomach, so it is a great doubt about the efficacy of oils for decreasing ALP absorption in stomach. ${ }^{[8]}$

- The authors recommended bicarbonate in the management of ALP poisoning just in cases with $\mathrm{pH}<7$. This suggestion 
is against other studies and is based on unproven hypotheses. ${ }^{[6]}$

Thank you so much for your interesting study.

\section{Financial support and sponsorship}

Nil.

\section{Conflicts of interest}

There are no conflicts of interest.

Omid Mehrpour, Mohan Gurjar ${ }^{1}$

Medical Toxicology and Drug Abuse Research Center, Birjand University of Medical Sciences, Birjand, South Khorasan Province, Iran, 'Department of Critical Care Medicine, Sanjay Gandhi Postgraduate Institute of Medical

Sciences, Lucknow, Uttar Pradesh, India

Address for correspondence: Dr. Omid Mehrpour, Medical Toxicology and Drug Abuse Research Center, Birjand University of Medical Sciences, Moallem Avenue, Birjand 9713643138, South Khorasan

Province, Iran.

E-mail: omid.mehrpour@yahoo.com.au

\section{RefEREnCES}

1. Farahani MV, Soroosh D, Marashi SM. Thoughts on the current management of acute aluminum phosphide toxicity and proposals for therapy: An evidence-based review. Indian J Crit Care Med 2016;20:724-30.

2. Mehrpour O, Abdollahi M. Poison treatment centers in Iran. Hum Exp Toxicol 2012;31:303-4

3. Alizadeh AM, Hassanian-Moghaddam H, Shadnia S, Zamani N, Mehrpour O. Simplified acute physiology score II/acute physiology and chronic health evaluation II and prediction of the mortality and later development of complications in poisoned patients admitted to intensive care unit. Basic Clin Pharmacol Toxicol 2014;115:297-300.

4. Mohan B, Singh B, Gupta V, Ralhan S, Gupta D, Puri S, et al. Outcome of patients supported by extracorporeal membrane oxygenation for aluminum phosphide poisoning: An observational study. Indian Heart J 2016;68:295-301.

5. Oghabian Z, Mehrpour O. Treatment of aluminium phosphide poisoning with a combination of intravenous glucagon, digoxin and antioxidant agents. Sultan Qaboos Univ Med J 2016;16:e352-5.

6. Mehrpour O, Amouzeshi A, Dadpour B, Oghabian Z, Zamani N, Amini $\mathrm{S}$, et al. Successful treatment of cardiogenic shock with an intraaortic balloon pump following aluminium phosphide poisoning. Arh Hig Rada Toksikol 2014;65:121-6.

7. Mehrpour O, Jafarzadeh M, Abdollahi M. A systematic review of aluminium phosphide poisoning. Arch Ind Hyg Toxicol 2012;63:61-73.

8. Jafari A, Baghaei A, Solgi R, Baeeri M, Chamanara M, Hassani S, et al. An electrocardiographic, molecular and biochemical approach to explore the cardioprotective effect of vasopressin and milrinone against phosphide toxicity in rats. Food Chem Toxicol 2015;80:182-92.

This is an open access article distributed under the terms of the Creative Commons Attribution-NonCommercial-ShareAlike 3.0 License, which allows others to remix, tweak, and build upon the work non-commercially, as long as the author is credited and the new creations are licensed under the identical terms.

\begin{tabular}{|l|l|}
\hline \multicolumn{3}{|c|}{ Access this article online } \\
\hline Quick Response Code: & Website: \\
\hline & www.ijccm.org \\
\hline
\end{tabular}

How to cite this article: Mehrpour O, Gurjar M. Cardiogenic shock: The main cause of mortality in acute aluminum phosphide poisoning. Indian $\mathrm{J}$ Crit Care Med 2017;21:246-7.

(c) 2017 Indian Journal of Critical Care Medicine | Published by Wolters Kluwer - Medknow 